\title{
Correction to: Convergence model for effectual prevention and control of zoonotic diseases: a health system study on 'One Health' approach in Ahmedabad, India
}

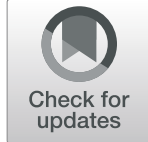

Sandul Yasobant ${ }^{1,2^{*}}$, Walter Bruchhausen ${ }^{1,3}$, Deepak Saxena ${ }^{4}$ and Timo Falkenberg ${ }^{1,5}$

\section{Correction to: Health Res Policy and Syst (2018) 16:124 https://doi.org/10.1186/s12961-018-0398-6}

It was highlighted that the original article [1] contained an error in the Methods section, specifically in Study Section. The number urban health centres should be 72 instead of 6 . This Correction article shows the incorrect and correct statement in the Methods section.

\section{Incorrect statement:}

The rural areas of Ahmedabad have one district hospital, six community health offices and 36 primary health centres [3], whereas the urban areas of Ahmedabad have six urban health centres, six medical colleges and one homeopathy college as well as being well facilitated by private companies for human health [2].

\section{Correct statement:}

The rural areas of Ahmedabad have one district hospital, six community health offices and 36 primary health centres [3], whereas the urban areas of Ahmedabad have 72 urban health centres, six medical colleges and one homeopathy college as well as being well facilitated by private companies for human health [2].

\footnotetext{
Author details

${ }^{1}$ Center for Development Research (ZEF), University of Bonn, Bonn, Germany. ${ }^{2}$ Faculty of Medicine, University of Bonn, Bonn, Germany. ${ }^{3}$ Institute of History and Ethics of Medicine, University of Cologne, Faculty of Medicine and University Hospital Cologne, Cologne, Germany. ${ }^{4}$ Indian Institute of Public Health Gandhinagar (IIPHG), Gujarat, India. ${ }^{5} \mathrm{GeoHealth}$ Centre, Institute for Hygiene and Public Health, University of Bonn, Bonn, Germany.
}

Published online: 09 August 2019

\section{References}

1. Yasobant, et al. Convergence model for effectual prevention and control of zoonotic diseases: a health system study on 'one health' approach in Ahmedabad, India. Health Res Policy Syst. 2018;16:124. https://doi.org/10.11 86/s12961-018-0398-6.

2. Ahmedabad Municipal Corporation. Ahmedabad city: Ahmedabad municipal Corporation. About Ahmedabad city. 2017. https:// ahmedabadcity.gov.in/ portal/jsp/Static_pages/about_us.jsp. Accessed 2 Jan 2018.

3. Ahmedabad District Panchayat, Government of Gujarat. Ahmedabad District Panchayat. 2017. https://ahmedabaddp.gujarat.gov.in/ahmedabad/sakhao/ pashupalan-shakha/prastavna.htm. Accessed 2 Jan 2018.

\footnotetext{
* Correspondence: yasobant@uni-bonn.de

'Center for Development Research (ZEF), University of Bonn, Bonn, Germany

${ }^{2}$ Faculty of Medicine, University of Bonn, Bonn, Germany

Full list of author information is available at the end of the article
}

(c) The Author(s). 2019 Open Access This article is distributed under the terms of the Creative Commons Attribution 4.0 International License (http://creativecommons.org/licenses/by/4.0/), which permits unrestricted use, distribution, and reproduction in any medium, provided you give appropriate credit to the original author(s) and the source, provide a link to the Creative Commons license, and indicate if changes were made. The Creative Commons Public Domain Dedication waiver (http://creativecommons.org/publicdomain/zero/1.0/) applies to the data made available in this article, unless otherwise stated. 